\title{
"This Broadcast Is Being Watched Live by Millions of Americans": Vague Language in Jimmy Kimmel's Oscars 2017 Opening Monologue
}

\author{
${ }^{1}$ Wahyuningsih, ${ }^{2}$ Nina Setyaningsih \\ ${ }^{1}$ Universitas Diponegoro, Semarang \\ ${ }^{2}$ Universitas Dian Nuswantoro, Semarang \\ ( ${ }^{1}$ ayunope@gmail.com, ${ }^{2}$ nina.setyaningsih@dsn.dinus.ac.id $)$
}

Article History: Submitted 19 November 2018; Accepted 28 November 2018; Published 31 December 2018

\begin{abstract}
When delivering a speech or talk,a speaker shares a great deal of background knowledge to the audience.However, as human being, the speaker often gets nervous and forgets the words to say. Sometimes the speaker is not able to memorize all information that s/hewants to present to the audience. In fact, during the talk, the speaker must speak fluently to maintain a good situation and communication to the audience. Therefore, to fill a gap during a talk becausethe speaker could not memorize every detail of information to bepresented,using vague language sometimes becomes an option. Vague language may also be used for other purposes besides nervousness and memory problem, i.e. as a tension management (Trappes-Lomax, 2007). This research explores vague language as tension management deviceused by Jimmy Kimmel as the host in the Oscars opening monologue in 2017. The method used in this research was qualitative descriptive since it describes the data in the form of word or sentence. The resultsdemonstrate that Jimmy Kimmel usedvague language types such as conventional indirectness, category and quantity approximation, hedges, modal expressions, implicitness, euphemisms, softeners and down toners as tension management devices.Furthermore, vague language can function as hedges forJimmy Kimmel's statements when the information he presented is not precise.
\end{abstract}

Keywords:Jimmy Kimmel, monologue, Oscars, tension management, vague language

\begin{abstract}
Abstrak.Ketika menyampaikan pidato atau ceramah, seorang pembicara berbagi apa yang ia ketahui kepada pendengarnya. Tetapi sebagai manusia pembicara sering mengalami grogi dan menjadi lupa akan apa yang akan dia sampaikan. Terkadangpembicaratidakdapat mengingat semua informasi yang akan disampaikannya. Padahal dalam pidato tersebut ia harus mampu berbicara lancar untuk menjaga situasi dan komunikasi pada para pendengarnya. Oleh sebab itu, salah satu cara untuk mengisi kekosongan atau diam karena pembicara tidak ingats eтиа detail informasi adalah denga nmenggunakan bahasa yang samar. Bahasa samar dapat juga digunakan untuk tujuan selain mengatasi kegugupan atau masalah ingatan, misalnya untuk mengelola ketegangan (Trappes-Lomax, 2007). Penelitian ini menjabarkan bahasa samar sebagai peran pengelola ketegangan yang digunakan Jimmy Kimmel ketika menjadi pembawa acara pada pembukaan penganugerahan Piala Oscar pada tahun 2017. Metode penelitian yang digunakan dalam penelitian ini adalah kualitatif deskriptif karena penelitian ini menjabarkan data dalam bentuk kata maupun kalimat. Hasilnya menunjukkan bahwa Jimmy Kimmel menggunakan jenis bahasa samar antara lain conventional indirectness, category and quantity approximation, hedges, modal expressions, implicitness, euphemisms, dan downtoners sebagai peran pengelola ketegangan. Selain itu, bahasa samar juga menjadi pagar pernyataan Jimmy Kimmel ketika informasi yang disampaikannya tidak tepat.
\end{abstract}

Kata kunci:Jimmy Kimmel, monolog, Piala Oscar, pengelolaan ketegangan, bahasa samar 


\section{INTRODUCTION}

Being a characteristic unique to human, language can deliberately express one's ideas and thoughts. Language enables human to communicate with each other. Language is used for various communication purposes in many situations, such as daily conversation and speech.

As mentioned above, speech or talk is a form of communication activity. Hence, in communication, it is essential to create good atmosphere between the speaker and the hearers. In dealing with this, McCarthy and Carter (2007:159) suggest the term "relational language" torefer to the language that serves to "create and maintain a good relationship interaction between the speaker and hearer". One of the language features commonly found in social interaction is vague language. Vague language may appear in both written and spoken communication. In a spoken communication for instance, when delivering a speech sometimes a speaker cannot memorize every detail of information to be presented, or perhaps the information is not exactly precise to the fact. In this case, using vague language may be the best choice to fill the gap.

Channell (1994) defines vague language as a language which "can be contrasted with another word or expression which appears to render the same proposition" and which is "purposely and unabashedly vague". Vague expressions show that meanings are themselves vague, and speakers share knowledge of how to understand them. As Channell (1994) notes, "any social group sharing interests and knowledge employs non-specificity in talking about their shared interest". Nonetheless, vague language is pervasive in everyday talk, serving interpersonal and pragmatic functions in discourse.

Vague language is found to be particularly common talk as speakers are often cautious not to sound over definite, which might be perceived as threatening (Carter \& McCarthy, 2006; Cheng \& Warren, 2003; O'Keeffe et al., 2007). O'Keeffe et al. (2007) also note that one central function of vague language is to hedge assertions or to make them fuzzy by allowing speakers to tone down what they say. In this regard, vague language softens expressions, so the speakers "do not appear too direct or unduly authoritative and assertive". Further, the use of vague expressions is a conscious choice by speakers and is not a product of careless thinking or sloppy expression (Carter \& McCarthy, 2006:202).

Vague language can have a socially cohesive function as strategies for dealing with various kinds of threats to positive or negative face. Thus, hedging expressions such as 'I think', 'I suppose', and 'maybe' may fall under vague language. Any linguistic device by which a speaker avoids being compromised by a statement that turns out to be wrong, a request that is not acceptable, and so on' (Matthews, 1997) is almost similar with tension management devices (TMD).In many cases, some TMD conveys a sufficient degree of information for the participants involved; therefore it is not necessary for speakers to be more precise.

A case of the use of vague language in speech can be seen in Jimmy Kimmel's opening monologue in Oscars. In the 2017 Oscars he said:

... I don't want to get too serious, but there are millions and millions of people watching right now, and if each and every one of you took a minute to reach out to one person you disagree with, someone you like, and have a positive, considerate conversation, not as liberals or conservatives, as Americans. (source: https://www.youtube.com/watch?v=fDkXHWMNNmc) 
Here he mentions number or quantity that is not exact. There must also be certain reasons why he chooses to say millions and millions instead of giving a precise number.

Considering this phenomenon, this research explores the vague language as tension management devices used by Jimmy Kimmel in the Oscars opening monologue in 2017 "This Broadcast is being watched by Millions of American". Jimmy Kimmel is a host and comedian from America. He is known for hosting the late-night show Jimmy Kimmel Live! on ABC (American Broadcasting Company).As a host, Jimmy Kimmel needs to share a great deal of knowledge and show a capability in communication. During his talk, vague expressions were used frequently. Therefore, this study concerns on Jimmy Kimmel's use of vague language and its functions in the Oscars opening monologue in 2017.

\section{Vague Language}

In a talk or common conversation, vague language serves the function of signaling the listener that the utterance, or part of it, is not to be interpreted precisely. Vague language comprises of a closed set of identifiable lexical items that can be interpreted with alternative view based on the particular context in which they occur. Crystal and Davy (1975:111-12) note that "the use of lexical vagueness is undoubtedly a main sign of social and personal relaxation". They give four reasons for vagueness. First, memory loss causes the speakers to forget the correct word. Second, the language has no suitable exact word, or the speaker does not know it. Third, the subject of the conversation is not such that it requires precision, and an approximation will do. Fourth, the choice of a vague item is deliberate to maintain the atmosphere.

Nearly in the same sense, Koester (2007:53) argues that when referring to facts and information, vague items are employed for the following reasons:

1. They have a cohesive function, where the referent is specified in the context.

2. The exact information may not be known.

3. It is not necessary to be more explicit, because implicit reference conveys sufficient information, because of the knowledge shared by the discourse participants as members of the same professional discourse community (this is the most frequent use).

In addition, Zhang (2011) provides a brief summary of the functions of vague language as follows:

1. Make an approximation or express vague quantity, for example in expressions such as about 20, a few, many

2. Intensify the tone of speech (example: very, obviously, really, so)

3. Soften the tone of speech (example: a bit, some, sort of, kind of)

4. Indicate a vague category (example: and all that, and things, or anything like that)

5. Indicate an unspecific meaning boundary signaled by a noun or pronoun (example: thing, things, someone, something, stuff) 
6. Convey a lower degree of speaker's certainty and commitment (example: I think, we believe, probably, maybe)

Vague language is a characteristic of natural language because natural language often states imprecise statement. Vague language is also an important grammatical and interpersonal feature of spoken discourse. Cutting (2007:19) says that studies of vague language views "language that is inherently and intentionally imprecise, describing lexical and grammatical surface features themselves that may refer either to specific entities or to nothing in particular." Biber et al. (1999:265) explains that vague language expresses imprecision that hedges and that in generic reference the noun "refers to a whole class rather than to an individual person or thing". Furthermore, Carter and McCarthy (2006) also describe vague expressions as words or phrases "which deliberately refer to people and things in a non-specific, imprecise way". These include expressions such as stuff, like, or anything, or whatever, sort of and approximations as in around six, five minutes or so, seven-ish, and loads and loads.

The interlocutors, in this case, do not need to convey precise and concrete information simply because they are accustomed to relying on a common ground of knowledge and belief shared with others. Carter (1998:45) sees it as a social leveler. It "puts the speakers on an immediately casual and equal footing with their interlocutors". This also accords with O'Keeffe et al.'s (2007:177) definition, that vague language indicates "assumed or shared knowledge and mark in-group membership". In other words, it is a marker of intersubjectivity.

Brown and Yule (1983:8-9) point out that spoken language usually requires limited syntax and contains a lot of "general, non-specific" vocabulary, which we term here vague language. Much vague language occurs with numbers or quantities to signal that they are to be interpreted as referring to a range rather than a specific quantity. Another large category is the vague lexical item, such as thing, that is often used instead of a more specific item. However, sometimes apparently precise statements can be used as approximations, as in Sam is six feet tall.

Channell (1994) offers three primary categories of vague lexis:

1. vague additives to numbers: a word or phrase is added to a precise figure to signal a vague reading (e.g. about, around, round, approximately $+n$ )

2. vagueness by choice of vague words or phrases (e.g. + and things, or something, and such, or anything; thing, thingy, what's name, whatnot)

3. Vagueness by scalar implicative (e.g. most, many, some, few, often, sometimes, occasionally, seldom).

In addition, categories 2 and 3 differ in that the meanings of the vague language items in category 3 are understood by the hearer/reader in relation to a range of terms that are ranked relative to one another in meaning.

\section{Tension Management Device}

Taking part in social encounters needs some kind of face or self-image. A speaker can try to avoid embarrassment by presenting a face that cannot be invalidated. As this is not 
always possible, the speaker must resort to management devices, for instance by speaking vaguely (saying general things) to protect her/his self-image (Trappes-Lomax, 2007). Furthermore, the conflict between what the speaker wants and does not want produces a tension which is reflected in the language used to cope with the situation. The speaker may avoid something as s/he is to achieve something, thus expressing her/his utterance in equivocation or indirectness, i.e. a mechanism for dealing with conflicting intentions and desires (Trappes-Lomax, 2007).

Matthews (1997) and Trappes-Lomax (2007) describes tension management devices as 'any linguistic device by which a speaker avoids being compromised by a statement that turns out to be wrong, a request that is not acceptable, and so on'. These devices include the following:

1. 'off-record' vagueness (such as hints)

2. violations of Gricean maxims

3. implicitness

4. conventional indirectness

5. category and quantity approximation

6. hedges

7. modal expressions

8. stance adverbials

9. questions and conditionals

10. euphemisms

11. softeners and down toners

12. metaphors and idioms.

When giving a talk as the host in Oscar's shows, Jimmy Kimmel began his talk with the words, 'Oh good, I got a sitting ovation. Awesome, I don't know what to say'. This is explained by Thomas (in Trappes-Lomax, 2007) that simply by speaking, one trespasses on another's space'. In a situation like an Oscars, the offense is also greater and more than usually noticeable. The speaker is imposing not just on only one but on many people as theinterlocutors, making claims on their time, their attention, and their interest. Hence, escape is impossible for the speaker. Therefore, the anxiety caused by speaking in front of a large audience is easy to understand.

\section{METHOD}

In analyzing the data, the researchers used qualitative descriptive method. The researchers analyzed the data by describing them in the form of words, clauses, or sentencesinstead of numbers and statistical calculation. The data of this research were obtained from the 
transcript of Jimmy Kimmel's Oscars opening monologues in 2017, taken from the website https://hollywoodreporter.com/news/jimmy-kimmel-s-opening-monologue-transcriptoscar-2017-980304 (Oscars 2017 This Broadcast is being watched by Millions of American", retrieved on 1 October 2018)

The transcript was downloaded and then the utterances were segmented. After they were segmented, these utterances were given codes in the form of numbers. Then, vague language expressions in the utterances were identified and analyzed by using TrappesLomax's framework on TMD. After that, they were categorized based on the types of TMD and the functions are interpreted. Finally a conclusion was drawn based on the data interpretation.

\section{RESULTS AND DISCUSSION}

This section focuses on the analysis of vague language found in the data that have been classified. The data analysis has provided findings related to vague language as the tension management devices,namely conventional indirectness, category andquantity approximation, hedges, modal expressions, stance adverbials, questions and conditionals, euphemisms and down toners, metaphors and idioms. These different categories will be elaborated in this section.

The vague expressions as tension management devices produced by Jimmy Kimmel in the Oscars 2017 opening monologue are summarized in the following table.

Table 1 List of vague language as TMD found in the monologue

\begin{tabular}{llll}
\hline No & \multicolumn{1}{c}{ TMD } & \multicolumn{1}{c}{ Vague expressions } \\
\hline 1 & Conventional indirectness & I would like, if you would \\
\hline 2 & Category and quantity approximation & Other guys, everybody, everyone, millions
\end{tabular}
(and millions) of $\mathrm{X}$, around the world, more than $\mathrm{X}$, thing, something, one Braveheart, every $\mathrm{X}$, each and every one, someone, those of you, black people, white people, a little, two to five, a lot of, all, all of, everyone, outsiders, some of you, five men but only one, any

\begin{tabular}{lll}
\hline 3 & Questions and Conditionals & Tag questions, type 1 and type 2 conditionals \\
\hline 4 & Euphemisms & $\begin{array}{l}\text { Well I've ruined the Oscars already, I don't } \\
\text { know what to say.,bowel movement }\end{array}$ \\
\hline 5 & Metaphors and Idioms & Bury the hatchet (= make peace) \\
\hline 6 & Hedges & Probably, I think, maybe, possibly, \\
\hline 7 & Stance adverbials & $\begin{array}{l}\text { Really, most importantly, very, apparently, so, } \\
\text { totally, pretty darn, barely }\end{array}$ \\
\hline 8 & Implicitness & $\begin{array}{l}\text { Oh good, I got a sitting ovation. Awesome; } \\
\text { That's gone, thanks to him.; I'm glad }\end{array}$ \\
& & Homeland Security let you in tonight \\
\hline 9 & Modals & Can, would \\
\hline 10 & Downtoners & Just \\
\hline
\end{tabular}


While the vague expressions serve different functions. These functions are summed up below:

Table 2 Functions of vague language in the monologue

\begin{tabular}{lll}
\hline No & \multicolumn{1}{c}{ Functions } & \multicolumn{1}{c}{ Examples } \\
\hline 1 & $\begin{array}{l}\text { To avoid being explicit and to } \\
\text { show politeness }\end{array}$ & $\begin{array}{l}\text { And tonight, in the spirit of healing and bringing } \\
\text { people together, I would like to bury the hatchet } \\
\text { with someone I've had issues with. }(21 / 2017)\end{array}$
\end{tabular}

Some of you will get to come up here on this stage tonight and give a speech that the president of the United States will tweet about in all caps during his 5 a.m. bowel movement tomorrow, and I think that's pretty darn excellent if you ask me, so let's get going. (75/2017)

2 To make speech brief and easier for the audiences to understand than to mention exact details

So I'm going to enjoy this while I'm here. This broadcast is being watched live by millions of Americans and around the world in more than 225 countries that now hate us. (10/2017)

It was an astonishing physical transformation that hasn't been attempted since every actress, in every role ever. $(62 / 2017)$

It has been an amazing year for movies, black people saved NASA and white people saved jazz. (38/2017)

3 To avoid being wrong Apparently, Denzel had always wanted to work with Denzel and it just so happened that their schedules worked out. (54/2017)

That was a fun movie, wasn't it? (49/2017)

4 To hedge the statement in case what the speaker saidis contrary to the fact

$5 \quad$ To make the utterance soften
He was terrific and I want to say, on your behalf, I really hope the other guys from *NSYNC were watching that performance because if they were I think there's a really good chance that they're going to let you back in the band. (3/2017)

Too often the Academy only recognizes movies people have seen, and I just think it's wonderful. $(64 / 2017)$

Oh good, I got a sitting ovation. Awesome. $(1 / 2017)$

6 To convey a lower degree of I'm not the man to unite this country, but it can be speaker's certainty and done. $(18 / 2017)$

commitment

Matt, as you probably know, could have starred in Manchester by the Sea. (29/2017)

I think that is an amazing thing. (11/2017)

\begin{tabular}{lll}
\hline 7 & To shift power to audiences & Thank you for letting me be a part of this. (7/2017) \\
\hline 8 & Intensify the tone of speech & $\begin{array}{l}\text { Where is Andrew? You can barely even see him he } \\
\text { got so thin. (61/2017) }\end{array}$ \\
\hline
\end{tabular}




\section{Conventional indirectness}

The following utterances contain conventional indirectness. In utterance69/2017, Jimmy Kimmel uses polite request to actress Meryl Streep. He politely asks Meryl Streep to stand up and asks the audience to give applause to her. It shows indirectness since Jimmy Kimmel wants to ask Meryl Streep, but he does not say to the point the message that he wants to deliver. He prefers using this indirectness way as tension management device to avoid being explicit in asking her to stand up and to show politeness to the audiences since Meryl Streep is a senior actress and it was her $20^{\text {th }}$ Oscars nomination.

In utterance 57/2017, Jimmy Kimmel says that he represents the audience who did not watch the movie Elle. In this event, the actress from France, Isabelle Huppert, was there with them in the Oscars. Isabelle was nominated for her role in the Elle movie. Kimmel's saying "on behalf of everyone here" can be considered as a way of lessening the burden of not watching the movie since he also mentions the audience in his utterance.

Table 3 Result - Interpretation of conventional indirectness

\begin{tabular}{cl}
\hline Data no. & \multicolumn{1}{c}{ Text } \\
\hline $21 / 2017$ & $\begin{array}{l}\text { And tonight, in the spirit of healing and bringing } \\
\text { people together, I would like to bury the hatchet } \\
\text { with someone I've had issues with. }\end{array}$ \\
\hline $57 / 2017$ & $\begin{array}{l}\text { On behalf of everyone hereI would like to say we } \\
\text { didn't see Elle, but we absolutely loved it. }\end{array}$ \\
\hline $69 / 2017$ & Meryl, stand up if you would. \\
\hline
\end{tabular}

\section{Category and Quantity Approximation}

The vague expressions belonging to this category found in Jimmy Kimmel's Oscars 2017 monologue function to avoid making a commitment to look at exact details of specific themes, and to make the speech brief. Jimmy Kimmel uses approximations among others more than, millions of, a lot of, every-, some and those of you, two to five, and all. It can also be caused by his lack of informative details about numbers or persons.

The expression millions of as can be found in utterance 10/2017 can function to make Jimmy Kimmel's speech brief and easier for the audiences to understand than to mention the detailed number. In fact, Jimmy does not recognize all American people's name. Meanwhile, the word around the world in utterance 10/2017 can function to fill gap for Jimmy is not sure which part of the world or which countries watched the Oscars. However, he is sure that the show is watched not only by people in the United States but also in many other countries. That is why he chooses the phrase around the world.

The expression more than 225 countries in utterance 10/2017meansthat not only exactly 225 countries hate them but it can be more than what he just stated. Therefore, vague expression more than is used by Jimmy Kimmel to estimate the number of the countries.

The function of every, everyone, everybody as in utterances 19/2017, 69/2017, and 70/2017 is to make Jimmy Kimmel's speech more efficient than mentioning all actors' names and all roles. Even though such expressions are considered vague, they can be understood by audience well. 
Meanwhile, the vague expressions such as black people and white people in Jimmy Kimmel's utterance 38/2017 can be used to avoid being wrong for his statement. Jimmy Kimmel may not know the exact information contained in the utterance. Otherwise, he may not want to reveal the specific names of the people who are of African American origins who saved NASA and the white ones who saved jazz.

In utterance 26/2017 and 75/2017 Jimmy Kimmel uses vague expression those of you and some of you. In these utterances, he refers to the audience but does not mention the specific persons. In 26/2017 for instance, he talks about Matt Damon whom he said is a selfish person. There are people in the audience who have worked with Matt Damon, but he uses those of you instead of mentioning names to refer to these people. The reason is that he is not sure which people have worked with Matt Damon among the audiences, that is why he uses such expression.

Table 4 Result - Interpretation of category and quantity approximation

\begin{tabular}{|c|c|}
\hline Data no. & Text \\
\hline $10 / 2017$ & $\begin{array}{l}\text { So I'm going to enjoy this while I'm here. This broadcast is } \\
\text { being watched live by millions of Americans and around } \\
\text { the world in more than } \mathbf{2 2 5} \text { countries that now hate us. }\end{array}$ \\
\hline $11 / 2017$ & $\begin{array}{l}\text { I think that is an amazing thing. As you know - I don't have } \\
\text { to tell anybody - the country is divided right now. }\end{array}$ \\
\hline $12 / 2017$ & $\begin{array}{l}\text { I've been getting a lot of advice. People have been telling } \\
\text { me, "It's time to bring everyone together." }\end{array}$ \\
\hline 19/2017 & $\begin{array}{l}\text { You know, if every person watching this show - I don't } \\
\text { want to get too serious, but there are millions and millions of } \\
\text { people watching right now, and if each and every one of } \\
\text { you took a minute to reach out to one person you disagree } \\
\text { with, someone you like, and have a positive, considerate } \\
\text { conversation, not as liberals or conservatives, as Americans. }\end{array}$ \\
\hline $26 / 2017$ & $\begin{array}{l}\text { He's a selfish person — those of you who've worked with } \\
\text { him know this. }\end{array}$ \\
\hline $27 / 2017$ & g very unselfish. \\
\hline $38 / 2017$ & $\begin{array}{l}\text { novies, black people saved } \\
\text { zz. }\end{array}$ \\
\hline $46 / 2017$ & $\begin{array}{l}\text { u can expect your Oscar to arrive in two } \\
\text { s. }\end{array}$ \\
\hline $50 / 2017$ & $\begin{array}{l}\text { I don't know what's going on but there are a lot of sad } \\
\text { movies this year. }\end{array}$ \\
\hline $51 / 2017$ & $\begin{array}{l}\text { Of all the nominees, the only happy ending of all of the } \\
\text { nominees, was the one in the middle of Moonlight. }\end{array}$ \\
\hline 69/2017 & $\begin{array}{l}\text { Meryl, stand up if you would. Everybody please join me in } \\
\text { giving Meryl Streep a totally undeserved round of applause. }\end{array}$ \\
\hline $70 / 2017$ & The highly overrated Meryl Streep, e \\
\hline $73 / 2017$ & $\begin{array}{l}\text { I think it's important, this is important, I know that we've all } \\
\text { seen it all, but it's important that we take a second to } \\
\text { appreciate what is happening here. }\end{array}$ \\
\hline $75 / 2017$ & $\begin{array}{l}\text { Some of you will get to come up here on this stage tonight } \\
\text { and give a speech that the president of the United States will } \\
\text { tweet about in all caps during his } 5 \text { a.m. bowel movement } \\
\text { tomorrow, and I think that's pretty darn excellent if you ask } \\
\text { me, so let's get going. }\end{array}$ \\
\hline
\end{tabular}




\section{Questions and Conditionals}

Conditionals expressions refer to possible condition and its probable result based on fact. In the monologue, Jimmy Kimmel uses conditional as in utterance 3/2017. He makes a statement about the condition in which he expresses factual implications for uncertain circumstance since he is not sure whether the members of the band NSYNC were watching that performance or not. Thus, he'd rather use conditional because he really hopes so.

In addition, Jimmy Kimmel also uses question expressionssuch as in utterance 72/2017.In general communication, question expression is an important part of showing politeness. In 72/2017, he compliments Meryl Streep's dress. However, he does it as an implicit way of teasing Meryl Streep by asking whether her dress was made by Ivanka (Trump).While in 61/2017, he gives questions about Andrew Garfield presence. This functions as a way to interact with the audience in maintaining good atmosphere and to keep the audience paying attention to him during his talk. Therefore, it makes situation not too weary since there is a communication.

Another type of question found in this monologue is question tag. The examples are found in utterances 49/2017 and 52/2017. In utterance 49/2017, Jimmy Kimmel says it with raising intonation. It means that he is less sure that the movie Manchester by the Sea was a fun movie or not. In contrast, 52/2017 is articulated with a falling intonation. It suggests that Jimmy Kimmel is fairly sure that the audience did not watch the movie Moonlight. Because he is not completely sure, he still wants confirmation.

Table 5 Result - Interpretation of questions and conditionals

\begin{tabular}{ll}
\hline \multicolumn{1}{c}{ Data no. } & \multicolumn{1}{c}{ Text } \\
\hline $49 / 2017$ & That was a fun movie, wasn't it? \\
\hline $52 / 2017$ & You didn't watch it, did you? \\
\hline $61 / 2017$ & $\begin{array}{l}\text { Where is Andrew? You can barely even see him he got so } \\
\text { thin. There he is - he lost } 40 \text { pounds for his role in the } \\
\text { movie Silence. }\end{array}$ \\
\hline $72 / 2017$ & Nice dress by the way, is that an Ivanka? \\
\hline $3 / 2017$ & $\begin{array}{l}\text { He was terrific and I want to say, on your behalf, I really } \\
\text { hope the other guys from *NSYNC were watching that } \\
\text { performance because if they were I think there's a really } \\
\text { good chance that they're going to let you back in the band. }\end{array}$ \\
\hline $19 / 2017$ & $\begin{array}{l}\text { You know, if every person watching this show - I don't } \\
\text { want to get too serious, but there are millions and millions } \\
\text { of people watching right now, and if each and every one of } \\
\text { you took a minute to reach out to one person you disagree } \\
\text { with, someone you like, and have a positive, considerate } \\
\text { conversation, not as liberals or conservatives, as Americans. }\end{array}$ \\
\hline $\begin{array}{l}\text { If we would all do that we could make America great } \\
\text { again }- \text { we really could. It starts with us. }\end{array}$ \\
\hline \begin{tabular}{l} 
If he wins, he'll be able to go to any college he wants \\
\hline $41 / 2017$
\end{tabular} \\
\hline $\begin{array}{l}\text { If you win tonight you can expect your Oscar to arrive in } \\
\text { two to five business days. }\end{array}$
\end{tabular}




\section{Euphemisms}

Euphemism deals with indirect expressions especially the ones that are considered too harsh. It is also used to show modesty and to show politeness. Euphemisms as tension management device are also found in the monologue.

The phrase bowel movement in utterance 75/2017 shows politeness rather than be explicit since the real meaning of this phrase is an act of defecation. Therefore, since the show is broadcasted on TV and watched by public, it is more appropriate to say bowel movement instead of a more casual term such as poop.

In utterance 7/2017, Jimmy Kimmel uses the expression Thank you for letting me to show his modesty that makes audiences feel elevated. In general, someone says thank you when receiving something but in this case, Jimmy does not receive anything, hence he said thank you to shift power and to give compliment to audiences.

Table 6 Result - Interpretation of Euphemisms

\begin{tabular}{ll}
\hline Data no. & \multicolumn{1}{c}{ Text } \\
\hline $75 / 2017$ & $\begin{array}{l}\text { Some of you will get to come up here on this stage tonight } \\
\text { and give a speech that the president of the United States will } \\
\text { tweet about in all caps during his } 5 \text { a.m. bowel movement } \\
\text { tomorrow, and I think that's pretty darn excellent if you ask } \\
\text { me, so let's get going. }\end{array}$ \\
\hline $7 / 2017$ & Thank you for letting mebe a part of this. \\
\hline
\end{tabular}

\section{Downtoners}

According to Cambridge online dictionary, downtoners are words or phrases that reduce the force of another word or phrase. The expression just in 64/2017 softens Jimmy Kimmel's utterance and it shows modesty. It is also used to avoid appearing to overstate his opinion. Similarly, in 75/2017 he uses the word pretty to reduce the intensity of his statement since he also uses the word darn that gives amplifying tone to his opinion.

Table 7 Result - Interpretation of downtoners

\begin{tabular}{cl}
\hline Data no. & \multicolumn{1}{c}{ Text } \\
\hline $64 / 2017$ & $\begin{array}{l}\text { Too often the Academy only recognizes movies people have } \\
\text { seen, and I just think it's wonderful. }\end{array}$ \\
\hline $75 / 2017$ & $\begin{array}{l}\text { Some of you will get to come up here on this stage tonight } \\
\text { and give a speech that the president of the United States will } \\
\text { tweet about in all caps during his } 5 \text { a.m. bowel movement } \\
\text { tomorrow, and I think that's pretty darn excellent if you } \\
\text { ask me, so let's get going. }\end{array}$ \\
\hline
\end{tabular}

\section{Metaphors and Idioms}

In public speaking, the offense is sometimes bigger than daily conversation. In an international event such as the Oscars, the similar problem also occurs. The host is compelled to behave to not only one listener but also the audiences. When the audiences come from a diversity of areas and they have varieties of knowledge, the background knowledge of the host is essential. Hence, the use of idiomatic expression seems to show the host's knowledge. 
In the data, idiomatic expression is found in Jimmy Kimmel's utterance. An example is tobury the hatchet as in utterance 21/2017. This phrase can be said as idiomatic phrase since it contains hint and is not interpreted literally. In addition, this expression may function to share knowledge and to make the situation not too weary.

This vague language expressed by Jimmy Kimmel can also function as a way of avoiding being explicit. It means that he wants to stop an argument and makes peace with someone there that he had issues before, who is the actor Matt Damon. Jimmy Kimmel commends Matt Damon for his unselfishness of giving a role to Casey Affleck. In this utterance, Kimmel prefers using idiomatic phrase to share knowledge, otherwise it is used to hedge if the real meaning is not acceptable for the audience.

Table 8 Result - Interpretation of idioms

\begin{tabular}{cl}
\hline Data no. & \multicolumn{1}{c}{ Text } \\
\hline $21 / 2017$ & $\begin{array}{l}\text { And tonight, in the spirit of healing and bringing people } \\
\text { together, I would like to bury the hatchet with someone } \\
\text { I've had issues with. }\end{array}$ \\
\hline
\end{tabular}

\section{Hedges}

Vague expression such as probablymay function to convey a lower degreeof avoiding being wrongwhen Jimmy Kimmel says things that are still uncertain. In other words, these expressions show imprecision or express doubt. In addition, vague I think functions as a device for hedging by which he avoids being compromised by a statement that turns out to be wrong. Later, the audiences will not claim if they know the information is not precise to the fact.

Further, the hedges expressed by Jimmy Kimmel function as self-protection. They also function to convey a lower degree of his certainty and commitment. Hedges are safeguards against later being exposed as wrong.

The bold parts in the utterances below are indicated vague expressions because they show Jimmy Kimmel's uncertainty. The information can be the same to the fact or maybe not.

Table 9 Result - Interpretation of hedges

\begin{tabular}{ll}
\hline Data no. & \multicolumn{1}{c}{ Text } \\
\hline $9 / 2017$ & $\begin{array}{l}\text { This is my first time here }- \text { and the way you people go } \\
\text { through hosts, this is probably my last time here. }\end{array}$ \\
\hline $11 / 2017$ & $\begin{array}{l}\text { I think that is an amazing thing. As you know - I don't } \\
\text { have to tell anybody - the country is divided right now. }\end{array}$ \\
\hline $17 / 2017$ & I think the Scientology is working, I really do. \\
\hline $29 / 2017$ & $\begin{array}{l}\text { Matt, as you probably know, could have starred } \\
\text { in Manchester by the Sea. }\end{array}$ \\
\hline $36 / 2017$ & $\begin{array}{l}\text { And I want to say, maybe this is not a popular thing to say, } \\
\text { but I want to say thank you to President Trump. }\end{array}$ \\
\hline $47 / 2017$ & Possibly stolen by a GrubHub delivery man. \\
\hline $53 / 2017$ & $\begin{array}{l}\text { I don't know, you probably heard the story of how it came } \\
\text { together. }\end{array}$ \\
\hline $64 / 2017$ & $\begin{array}{l}\text { Too often the Academy only recognizes movies people have } \\
\text { seen, and I just think it's wonderful. }\end{array}$ \\
\hline $73 / 2017$ & I think it's important, this is important, I know that we've all \\
\hline
\end{tabular}


seen it all, but it's important that we take a second to

appreciate what is happening here.

\section{Stance Adverbials}

Stance adverbials convey a speaker's personal feelings, assessments, attitudes, or judgments. In the Oscars 2017 opening monologue, Jimmy Kimmel uses stance adverbials mostly to intensify his utterances. For instance, vague expression so thin is used to emphasize that Andrew Garfield lost 40 pounds for his role in the movie Silence. Moreover, Jimmy Kimmel uses vague thin since he does not measure Andrew's weight, but he sees that Andrew is thinner than others are.

Table 10 Result - Interpretation of stance adverbials

\begin{tabular}{ll}
\hline \multicolumn{1}{c}{ Data no. } & \multicolumn{1}{c}{ Text } \\
\hline $3 / 2017$ & $\begin{array}{l}\text { He was terrific and I want to say, on your behalf, I really } \\
\text { hope the other guys from *NSYNC were watching that } \\
\text { performance because if they were I think there's a really } \\
\text { good chance that they're going to let you back in the band. }\end{array}$ \\
\hline $6 / 2017$ & $\begin{array}{l}\text { Welcome. Welcome, and most importantly, } \\
\text { congratulations. }\end{array}$ \\
\hline $20 / 2017$ & $\begin{array}{l}\text { If we would all do that we could make America great again } \\
\text {-we really could. It starts with us. }\end{array}$ \\
\hline $40 / 2017$ & Tonight is very important for Damien. \\
\hline $54 / 2017$ & $\begin{array}{l}\text { Apparently, Denzel had always wanted to work with } \\
\text { Denzel and it just so happened that their schedules worked } \\
\text { out. }\end{array}$ \\
\hline $61 / 2017$ & $\begin{array}{l}\text { Where is Andrew? You can barely even see him he got so } \\
\text { thin. }\end{array}$ \\
\hline $69 / 2017$ & $\begin{array}{l}\text { Meryl, stand up if you would. Everybody please join me in } \\
\text { giving Meryl Streep a totally undeserved round of applause. }\end{array}$ \\
\hline $70 / 2017$ & The highly overrated Meryl Streep, everyone. \\
\hline
\end{tabular}

\section{Implicitness}

In Oscars 2017 monologue there are expressions that are implied indirectly. Utterance 1/2017 is the opening of the show. All of the audience but Justin Timberlake did not give him a standing ovation. When he says "Oh good I good a standing ovation. Awesome" he actually means the opposite so as to avoid being explicit. He claims attention from the audience since there is no standing ovation when he came to the stage.

In utterance 58/2017, Jimmy Kimmel welcomes French actress Isabelle Huppert. He wants to imply that Isabelle Huppert is not an American and that as a foreigner or outsider, she can enter the United States without any problem since the US Homeland Security let her come to US and attend the Oscars.

Table 11 Result - Interpretation of implicitness

\begin{tabular}{ll}
\hline \multicolumn{1}{c}{ Data no. } & \multicolumn{1}{c}{ Text } \\
\hline $1 / 2017$ & Oh good, I got a sitting ovation. Awesome. \\
\hline $37 / 2018$ & $\begin{array}{l}\text { I mean, remember last year when it seemed like the Oscars } \\
\text { were racist? That's gone, thanks to him. }\end{array}$ \\
\hline $58 / 2017$ & You were amazing in that film, and I'm glad Homeland \\
\hline
\end{tabular}


Security let you in tonight, I really am.

\section{Modals}

Some modals are considered vague since they show possibility rather than fact. The modal verbs such as can and would may function to express ability or possibility when the speaker lacks real information.

Table 12 Result - Interpretation of modals

\begin{tabular}{cl}
\hline \multicolumn{1}{c}{ Data no. } & \multicolumn{1}{c}{ Text } \\
\hline $18 / 2017$ & I'm not the man to unite this country, but it can be done. \\
\hline $22 / 2017$ & I would. Matt Damon. \\
\hline
\end{tabular}

Jimmy Kimmel uses modal verbs in the monologue, for instance in the utterances in Table 12. In 18/2017, Jimmy Kimmel uses modal can be to express the possibility of uniting the country.In this case, even though Jimmy is not the man who can unite the country, implicitly he assures that it is possible to be done by anyone else.

The modal also appears in expression 22/2017. This utterance contains the modal verb would. The context of this utterance is that Jimmy Kimmel wants to make peace with Matt Damon. He uses modal verb would to be more polite and less direct.

\section{CONCLUSION}

This research analyzes the vague language as tension management devices used by Jimmy Kimmel in the Oscars 2017 opening monologue. Although Jimmy Kimmel is a notable host and comedian, he demonstrates vague expressions as tension management devices in this event. His monologue contains various vague expression types such as conventional indirectness, category and quantity approximation, hedges, modal expressions, implicitness, euphemisms, softeners and down toners. These expressions serve the functions among others to avoid being explicit and to show politeness, to make speech brief and easier for the audiences to understand than to mention exact details, to avoid being wrong, to hedge the statement in case what Jimmy Kimmel said is contrary to the fact, to make the utterance soften, to convey a lower degree of his certainty and commitment, to shift power to audiences, and to intensify the tone of his speech.

The study has demonstrated that the tension experienced by a speaker in a vast level of public speaking causes the speaker to produce vague utterances. In such a situation, vague language helps the speaker to provide adequate information to the audience and to hedge utterances when the speaker lacks specific details to be presented.

\section{REFERENCES}

Biber, D., Johansson, S., Leech, G., Conrad, S., \&Finegan, E. (1999). Longman grammar of spoken and written English. Harlow, England: Longman.

Brown, G., and G. Yule.(1983). Discourse analysis. Cambridge: Cambridge University Press. 
Crystal, Davy.(1975).Vague expression in English: Studies in language and communication. In Giuliana Garzone,James Archibald (Ed), Discourse, Identities and Roles in Specialized Communication (pp.87-90).Peter Lang AG, International Academic Publisher, Bern 2010.

Carter, R., \& McCarthy, M. (2006).Cambridge grammar of English: A comprehensive guide. Cambridge: Cambridge University Press.

Channell, J. (1994). Category of vague language: The use of vague language accros spoken genres in an intercultural Hong Kong corpus. In J.Cutting (Ed), Vague language explored (p.161-2)

Cutting, J. (2007). Introduction to vague language explored. In J. Cutting (Ed.),Vague language explored (pp. 3-26). New York Basingstoke.

Koester, A. (2007). "About twelve thousand or so": Vagueness in north American and UK offices. In J. Cutting (Ed), Vague language explored (pp. 40-61). Basingstoke: Palgrave Macmillan.

O'Keeffe, A., McCarthy, M., \& Carter, R. (2007). "Relational language" From corpus to classroom: Language use and language teaching. Cambridge: Cambridge University Press

Trappes-Lomax, Hugh. (2007). Vague language as a means of self-protective avoidance: Tensionmanagement in conference talks. In Joan Cutting (ed.), Vague Language Explored, 117-137.Hampshire: Palgrave Macmillan

Cheng, Winnie and M. Warren,(2001).The use of vague language in intercultural conversations in Hong Kong. Article in English World-Wide 81-104. https://www.researchgate.net/publication/233613944

Zhang, Grace. (2011). Elasticity of vague language. Intercultural Pragmatics, 8-4, 571599. DOI 10.1515/IPRG.2011.026 


\section{APPENDIX}

\section{"This broadcast is being watched live by millions of Americans and around the world in more than 225 countries that now hate us."}

Jimmy Kimmel took aim at Damien Chazelle, Manchester by the Sea, Donald Trump and, of course, his longtime nemesis Matt Damon - during his opening monologue at the 89th annual Academy Awards on Sunday night.

Oh good, I got a sitting ovation. Awesome. Well I've ruined the Oscars already, I don't know what to say. Welcome everybody, thanks Justin Timberlake. He was terrific and I want to say, on your behalf, I really hope the other guys from *NSYNC were watching that performance because if they were I think there's a really good chance that they're going to let you back in the band. I do. Thank you very much, Justin.

Hi, everybody. Welcome. Welcome, and most importantly, congratulations. Congratulations everyone who's nominated tonight. Thank you for letting me be a part of this. I'm excited. I've never been to the Oscars before. This is my first time here - and the way you people go through hosts, this is probably my last time here. So I'm going to enjoy this while I'm here. This broadcast is being watched live by millions of Americans and around the world in more than 225 countries that now hate us.

I think that is an amazing thing. As you know - I don't have to tell anybody - the country is divided right now. I've been getting a lot of advice. People have been telling me, "It's time to bring everyone together. You need to say something to unite us." Let's just get something straight off the top, I'm not - I can't do that. There's only one Braveheart in this room and he's not going to unite us either, OK. Mel, you look great. I think the Scientology is working, I really do. I'm not the man to unite this country, but it can be done. You know, if every person watching this show - I don't want to get too serious, but there are millions and millions of people watching right now, and if each and every one of you took a minute to reach out to one person you disagree with, someone you like, and have a positive, considerate conversation, not as liberals or conservatives, as Americans. If we would all do that we could make America great again - we really could. It starts with us.

And tonight, in the spirit of healing and bringing people together, I would like to bury the hatchet with someone I've had issues with. I would. Matt Damon. Now Matt, I've known Matt for a long time. I've known Matt so long, when I first met Matt, I was the fat one. True. And we've had problems. He's a selfish person - those of you who've worked with him know this. But Matt did something very unselfish. And I want to commend him for it. For real. Matt, as you probably know, could have starred in Manchester by the Sea. He was the producer, it's nominated for six Oscars including lead actor, and he could have taken that lead actor part for himself, but he didn't. He gave that role to Casey Affleck, his childhood friend. He handed what turned out to be an Oscar-caliber role over to his friend, and made a Chinese-ponytail movie instead. And that movie, The Great Wall, went on to lose $\$ 80$ million. Smooth move, dumbass. See, it's so easy to reach out and heal. And I want to say, maybe this is not a popular thing to say, but I want to say thank you to President Trump. I mean, remember last year when it seemed like the Oscars were racist? That's gone, thanks to him.

It has been an amazing year for movies, black people saved NASA and white people saved jazz. That's what you call progress. A little movie musical named La La Land ties the all- 
time Oscar record. It was directed by Damien Chazelle. Fourteen nominations. Fourteen nominations, one for every year Damien has been alive. Tonight is very important for Damien. If he wins, he'll be able to go to any college he wants, so we wish you the best.

The movie business is changing. For the first time ever, Amazon is represented at the Academy Awards. Amazon is the first streaming service nominated for best picture. Jeff Bezos is the founder and CEO, and I want to say congratulations to Jeff. And I also want you know, Jeff, if you win tonight you can expect your Oscar to arrive in two to five business days. Possibly stolen by a GrubHub delivery man.

Amazon produced Manchester by the Sea. That was a fun movie, wasn't it? You know if you search for Manchester by the Sea on Amazon, it says customers who bought for this item also purchased Zoloft.

I don't know what's going on but there are a lot of sad movies this year. Of all the nominees, the only happy ending of all of the nominees, was the one in the middle of Moonlight. You didn't watch it, did you? "Oh, we love it so much!" The incredible Denzel Washington is nominated for Fences, a movie he also directed. I don't know, you probably heard the story of how it came together. Apparently, Denzel had always wanted to work with Denzel and it just so happened that their schedules worked out. And the rest is Oscar history. Congratulations to you, my friend.

We have friends and colleagues visiting from all around the world tonight. The great actress from France, Isabelle Huppert is here with us. Isabelle, as we know is nominated for her performance in the movie Elle, and on behalf of everyone here I would like to say we didn't see Elle, but we absolutely loved it. You were amazing in that film, and I'm glad Homeland Security let you in tonight, I really am.

We are very welcoming to outsiders here in Hollywood. We don't discriminate against people based on what countries they come from - we discriminate against them based on their age and weight. Andrew Garfield lost 40 pounds. Where is Andrew? You can barely even see him he got so thin. There he is - he lost 40 pounds for his role in the movie Silence. It was an astonishing physical transformation that hasn't been attempted since every actress, in every role ever.

Viggo Mortensen, who's terrific, is nominated for best actor for his performance in the movie Captain Fantastic and it is so well deserved. Too often the Academy only recognizes movies people have seen, and I just think it's wonderful.

We are here tonight to honor great actors, but we're also here to honor actors who seem great, but actually really aren't. And of all the great actors here in Hollywood, one in particular has stood the test of time for her many uninspiring and overrated performances. From her mediocre early work in The Deer Hunter and Out of Africa, to her underwhelming performances in Kramer vs. Kramer and Sophie's Choice, Meryl Streep has phoned it in for more than 50 films over the course of her lackluster career. This is Meryl's 20th Oscar nomination, made even more amazing considering the fact that she wasn't even in a movie this year - we just wrote her name down out of habit. Meryl, stand up if you would. Everybody please join me in giving Meryl Streep a totally undeserved round of applause. 
The highly overrated Meryl Streep, everyone. We're gonna have fun tonight — I hope we're gonna have fun tonight. Nice dress by the way, is that an Ivanka? This is exciting. I think it's important, this is important, I know that we've all seen it all, but it's important that we take a second to appreciate what is happening here: We're at the Oscars, the Academy Awards, you're nominated, you got to come, your families are nominated, your friends. Some of you will get to come up here on this stage tonight and give a speech that the president of the United States will tweet about in all caps during his 5 a.m. bowel movement tomorrow, and I think that's pretty darn excellent if you ask me, so let's get going. It's time for our first category tonight, supporting actor. It's what most actors' parents are still doing - supporting actors. Five men are nominated tonight, but only one will have the opportunity to be included in a spectacular clip montage like this.

Sources:

https://www.hollywoodreporter.com/news/jimmy-kimmel-s-opening-monologuetranscript-oscars-2017-980304

https://www.youtube.com/watch?v=fDkXHWMNNmc) 